\title{
Residual value of the phosphate added to ecuadorian and chilean soils with different phosphorus retention capacity
}

\author{
Gregorio Vásconez ${ }^{1,2}$ Dante Pinochet ${ }^{3 *}$ \\ ${ }^{1}$ Graduate School, Faculty of Agricultural Sciences, Universidad Austral de Chile, Casilla 567. Valdivia, Chile. \\ ${ }^{2}$ Faculty of Agricultural Sciences, Universidad Técnica Estatal de Quevedo, Casilla 73. Quevedo, Ecuador. \\ ${ }^{3}$ Institute of Agricultural Engineering and Soil Science, Universidad Austral de Chile, Casilla 567. Valdivia, \\ Chile.*Corresponding author:dpinoche@uach.cl; gvasconez@uteq.edu.ec
}

\begin{abstract}
The residual value of phosphorus addition is described by two reactions: a quick initial reaction followed by a slower reaction over time. In this study, the residual effect of two P sources was evaluated: monopotassium phosphate (MKP) and triple superphosphate (TSP) added to soils from Ecuador and Chile with contrasting soil P retention capacity. Olsen-P extractability was measured and compared in soil samples 1, 2, 4, 8, 15, 45, 90, 180 and 360 days after the addition. The Olsen-P extracted at 24 hours after the P addition varied among soils, and extracted between 10 and $66 \%$ of the P added depending upon the soil, with lower extraction values in soils with high P retention capacity. When the source was TSP, only approximately $70 \%$ of $\mathrm{P}$ was extracted compared to that extracted when MKP was added. After the phosphate addition there was a clear initial effect followed by a progressive loss of Olsen-P extractability. Furthermore, over time, a state of quasi-equilibrium or a stationary state become evident in which the loss of P extractability was minimal. When the initial effect was removed, as a point that characterizes different types of soils, the loss of $\mathrm{P}$ extractability was similar among soils, and reflects the amount of phosphate added despite the type of fertilizer used.
\end{abstract}

Keywords: Phosphate, Olsen-P, triple superphosphate, residual effect, volcanic soils 


\section{Introduction}

During a growing season, only a small fraction of the $\mathrm{P}$ added to a soil is removed at harvest time, leaving a fraction of it available for subsequent crops (McLaren et al., 2016). That fraction is called the residual value of the P applied (Syers et al., 2008). The reactions between $P$ and the soil matrix have been characterized as fast and slow reactions (Barrow, 1983; Barrow, 2015). The fast reactions are principally dependent upon the type of colloid and its proportion within the soil, while the slow ones are related to the laws that govern the intra-particle diffusion of ions (Barrow, 2017). When a particle of $\mathrm{P}$ fertilizer is added to the soil it quickly hydrates, initiating an emission of phosphate ions, which delimits a soil volume of influence (McLaughlin et al., 2011) which is characterized by two zones differing in their concentrations, a higher concentration of phosphate where precipitation reactions are dominant, while reactions of adsorption predominate with lower concentration. Phosphorus fertilizers have an effect on the soil within the volume of influence of each unit of fertilizer depending on the type of fertilizer composition and solubility (Montalvo et al., 2015). The Andes Mountains have had a strong influence on the formation of the diverse soil orders in Ecuador (Buytaert et al., 2007) and Chile (Luzio, 2010), by conditioning soil formation factors over time, such as parent material, topography, climate, and biologic activity (vegetation, macro and microorganisms). In Ecuador and Chile, the most representative soil orders include the Entisols, Vertisols, Inceptisols, Andisols, Mollisols, Ultisols and Alfisols (MAGAP, 2002; Luzio, 2010). Nevertheless, from the agronomic point of view, the Ecuadorian and Chilean Inceptisols and Andisols are of greatest interest since they represent more than $65 \%$ of their arable land (MAGAP, 2002; Luzio, 2010). An important characteristic of soils formed from volcanic materials is their high $\mathrm{P}$ retention capacity (Velásquez et al., 2016), which is reflected by the high $\mathrm{P}$ rates required to increase the available $\mathrm{P}$ in these soils (Rodríguez et al., 2001). The retention of $\mathrm{P}$ of Andisols varies among them but is higher than Mollisols, Alfisols, Entisols, Inceptisols and Ultisols.

The soil chemical test used to estimate the $\mathrm{P}$ availability in soils is validated by the proper calibration between the soil test value and the agronomic productivity and/or P uptake observed (Havlin et al., 2005; Ziadi et al., 2013). When these tests are properly calibrated they are used as tools to diagnose the fertility of a soil, in such a way that it has been possible to predict crop productivity or the productive response to a specific rate of P fertilizer (Sandaña y Pinochet, 2014). Ziadi et al. (2013) have shown that many methods are used to estimate $\mathrm{P}$ availability around the world. For instance, the Mehlich-3, Olsen and Kelowna methods are currently used in Canada, the Olsen, Bray-P1, Mehlich-3 and Morgan methods are used depending on the State in the United States, the Olsen, Bray-P1, and Morgan methods are used in Latin America (Ziadi et al., 2013), and in Chile and Ecuador the Olsen test is formally used (Cordova et al., 1996; Rodriguez et al., 2001). Once a soil chemical test is adopted to estimate $P$ availability, it is difficult to change, since the agronomic information related to fertilization practices of crops are generated on the basis of that methodology (Matus et al., 2005).

The agronomic value of Olsen-P to estimate the $\mathrm{P}$ available to crops (Selles et al., 2011) justifies the evaluation of the loss of $\mathrm{P}$ extractability and the residual value of $\mathrm{P}$ added from different types of phosphate fertilizers and in different types of soils in relation to soil P retention over time (Javid and Rowell, 2002; Barrow, 2015). We evaluated mainly soluble sources, assuming that all soluble $\mathrm{P}$ added would transfer into 
the soil solution and from there it would be subject to reactions with the soil, depending on the ability of each soil to retain P (Frossard et al., 2011). In this context, it is argued that the initial effect on P extractability is dependent on the retention capacity of each soil. After which, discounting that initial effect, the extractability among different types of soluble fertilizers and different types of soils would be similar and would depend on the diffusion of intraparticles in the soil. Consequently, this study evaluated the residual effect of $\mathrm{P}$ added, by measuring the loss in $\mathrm{P}$ extractability with Olsen-P test, in soils from Ecuador and Chile with different $\mathrm{P}$ retention capacity in an experiment of soil-fertilizer incubation.

\section{Materials and Methods}

\subsection{Soil sample characterization}

The soil samples were collected in seven locations in the Republic of Ecuador, six in the northern central region and one in the southern region. Puerto Quito, $\mathrm{La}$ Concordia, Pujilí and Santo Domingo are classified as Andisols; San Lorenzo and Quevedo are classified as Inceptisols; and Malacatos is classified as a Vertisol
Inceptisols; and Malacatos is classified as a Vertisol (southern region) (Beinroth et al., 1985). Three Chilean soils were also included, which are known to have differences in their P retentions. Malihue is classified as an Andisol, Cudico as an Ultisol and Rancagua as a Molisol (Rodriguez, 1993; Luzio, 2010). All of the soil samples were dried at air temperature and sieved at $2 \mathrm{~mm}$. The P retention of the soil samples was measured using the method described by Saunders (1965) with $\mathrm{KH}_{2} \mathrm{PO}_{4}$ in a solution $\left(1 \mathrm{mg} \mathrm{P} \mathrm{mL}^{-1}\right)$ of $\mathrm{NaOAc}-\mathrm{HAc}$, with a $\mathrm{pH}$ of 4.6. The soil samples were also characterized by measuring their $\mathrm{pH}$ in a solution of $0.01 \mathrm{M} \mathrm{CaCl}_{2}\left(\mathrm{pHCaCl}_{2}\right)$, soil:solution with a ratio of $1: 2.5$; organic carbon (OC) by acid digestion in presence of $\mathrm{K}$ dichromate; extractable aluminium $\left(\mathrm{Al}_{\text {ext }}\right)$ in ammonium acetate $\mathrm{pH} 4.81$ $\mathrm{N}$, and exchangeable bases $(\mathrm{Ca}, \mathrm{Mg}, \mathrm{K}$ and $\mathrm{Na})$, in a $1 \mathrm{M}$ solution of ammonium acetate with a $\mathrm{pH}$ of 7.0, the calcium carbonate equivalent $\left(\mathrm{CaCO}_{3}\right)$ was evaluated by the reaction in a solution of $1 \mathrm{M} \mathrm{HCl}$ and a titration of free acid with a solution of $1 \mathrm{M}$ $\mathrm{NaOH}$ (all of the above methodologies are described in Sadzawka et al., 2004). Soil texture was measured using the hydrometer method described by Sandoval et al. (2012) (Table 1). 
Table 1. Identification and characteristics of the soil samples of the experiment.

\begin{tabular}{|c|c|c|c|c|c|c|c|c|}
\hline $\begin{array}{l}\text { Soil types and } \\
\text { country of } \\
\text { origin }\end{array}$ & $\begin{array}{c}\text { Index } \\
\text { Saunders } \\
\%\end{array}$ & $\begin{array}{c}\mathrm{Al}_{\text {ext. }} \\
\mathrm{mg} \\
\mathrm{kg}^{-1}\end{array}$ & $\begin{array}{c}\text { Bases } \\
\mathrm{cmol}_{\mathrm{c}} \mathrm{kg}^{-} \\
1\end{array}$ & $\mathrm{CaCO}_{3}$ & $\mathrm{OC}$ & $\begin{array}{c}\mathrm{pH} \\
\mathrm{CaCl}_{2}\end{array}$ & $\xi$ & Clay \\
\hline \multicolumn{9}{|l|}{ Ecuador } \\
\hline \multicolumn{9}{|l|}{ Andisol } \\
\hline Pto. Quito & 91.49 & 879 & 3.47 & 2 & 66.0 & 4.63 & 384 & 119 \\
\hline La Concordia & 90.46 & 857 & 14.94 & 8 & 36.6 & 5.76 & 320 & 111 \\
\hline Pujilí & 94.30 & 875 & 2.83 & 2 & 30.3 & 5.20 & 446 & 91 \\
\hline Sto. Domingo & 73.64 & 460 & 7.86 & 6 & 50.3 & 5.08 & 473 & 95 \\
\hline \multicolumn{9}{|l|}{ Inceptisol } \\
\hline San Lorenzo & 51.94 & 201 & 7.26 & 8 & 35.4 & 4.50 & 127 & 358 \\
\hline Quevedo & 50.61 & 164 & 10.48 & 4 & 36.2 & 5.73 & 408 & 266 \\
\hline \multicolumn{9}{|l|}{$\underline{\text { Vertisol }}$} \\
\hline Malacatos & 15.39 & 3 & 46.40 & 36 & 29.1 & 7.00 & 117 & 732 \\
\hline \multicolumn{9}{|l|}{ Chile } \\
\hline \multicolumn{9}{|l|}{ Andisol } \\
\hline Malihue & 98.22 & 891 & 10.98 & 2 & 116.3 & 4.69 & 147 & 269 \\
\hline \multicolumn{9}{|l|}{ Ultisol } \\
\hline Cudico & 63.87 & 279 & 11.98 & 1 & 43.2 & 4.85 & 320 & 406 \\
\hline \multicolumn{9}{|l|}{ Molisol } \\
\hline Rancagua & 8.23 & 6 & 16.84 & 35 & 11.4 & 6.05 & 326 & 164 \\
\hline
\end{tabular}

$\mathrm{Al}_{\text {ext }}$, extractable aluminium; Bases, sum of $\mathrm{Ca}, \mathrm{Mg}, \mathrm{K}$ and $\mathrm{Na} ; \mathrm{CaCO}_{3}$, calcium carbonate equivalent to its presence in the soil; OC, organic carbon.

To characterize the initial P reaction, each soil sample was treated with a $\mathrm{KH}_{2} \mathrm{PO}_{4}$ solution to add 100,200 , 300, 400 and $500 \mathrm{mg} \mathrm{P} \mathrm{kg}^{-1}$ (Sharpley et al., 1984). After 24 hours of incubation at a temperature of $25^{\circ} \mathrm{C}$ and a constant humidity ( $70 \%$ of maximum water retention capacity), Olsen-P was determined. The relationship was lineal and the slope between the $\mathrm{P}$ added and the $\mathrm{P}$ extracted by the Olsen-P test was referred to as the CP value of each soil (Rodríguez, 1993).
2.2. Long-term incubation of soil samples with the fertilizer

For this experiment, two sources of $\mathrm{P}$ with different degrees of solubility were selected, $\mathrm{KH}_{2} \mathrm{PO}_{4}(\mathrm{MKP}$, a completely soluble phosphate) and commercial triple superphosphate (TSP, with a relatively high solubility in water). The TSP was ground and characterized according to the methodologies described by the AOAC 
(1990). The TSP showed a total P concentration, water solubility and citrate solubility of 204.1, 142.0 and $33.7 \mathrm{~g} \mathrm{P} \mathrm{kg}^{-1}$, respectively. A unique rate of $500 \mathrm{mg} \mathrm{P} \mathrm{kg}^{-1}$ was used for the long-term incubation and a control with no $\mathrm{P}$ application was also considered. Each treatment was incubated in two repetitions for each soil and for each incubation time. The soil samples were put into containers of polyethylene and treated with the fertilizer sources. The containers covers were perforated to favour aerobic conditions. $\mathrm{KH}_{2} \mathrm{PO}_{4}$ was applied once it was diluted in water and TSP was applied in its solid form. The soil samples were incubated at a constant temperature $\left(25^{\circ} \mathrm{C}\right)$ and humidity $(70 \%$ of maximum water retention capacity) for a period of 360 days. The samples' loss of humidity was compensated for every seven days.

\subsection{Evaluation of the extractability of $P$ added}

The extractable Olsen-P was measured after 1, 2, $4,8,15,45,90,180$ and 360 days of incubation in a separate soil-fertilizer device, prepared for each measurement in two replicates. For each measurement, a subsample of humid soil was taken, equivalent to $2.5 \mathrm{~g}$ of dry soil. This was extracted by agitation with $50 \mathrm{~mL}$ of solution $\left(0.5 \mathrm{M}\right.$ of $\mathrm{NaHCO}_{3} \mathrm{pH}$ 8.5 ) for 30 minutes at 180 revolutions per minute. After the extraction process, the concentration of $\mathrm{P}$ was determined in the soil free extract by using colorimetry (Sadzawka et al., 2004).

\subsection{Statistical analysis}

To describe the actual effect of the new $\mathrm{P}$ added on time, to each Olsen-P value measured it was subtracted the respective control Olsen-P value (the Olsen-P value when no $\mathrm{P}$ was added). Through a regression analysis the Olsen-P extractability was described in relation to the incubation time $(1,2,4,8,15,45,90$, 180 and 360 days), establishing an exponential model of only one phase of association [a $\left.+b^{*}\left(1-\exp -k^{*} X\right)\right]$ which was assessed considering the value of $\mathrm{R} 2$ and the estimation error (Sy.x). The difference among the sources of $\mathrm{P}$ added was evaluated using a t-test at $5 \%$ to compare the parameters related to the loss of extractability of Olsen-P (k). Furthermore, the parameters of the exponential equation, "a", "b" and "k" were related to $\mathrm{CP}$ and expressed in relative terms to their values. To remove the initial effect of the $P$ retention capacity of each soil, the data were modelled in accordance with relative Olsen-P (OPRelative). The Olsen-P measured on day one (OP1) was expressed in a relative value of 1.0; once the process of incubation began in the fertilized soil subsequent measurements of Olsen-P $(\mathrm{OP}>1)$ were related to this unit, registering their proportionality with regards to the Olsen-P measured on day one (Equation 1). Where, OP $>1$ represents Olsen-P measured after 2, 4, 8, 15, 45, 90, 180 and 360 days of incubation and OP1 is provided by the Olsen-P measured after a day of incubation of the soil incubation.

$$
O P_{\text {Relative }}=\frac{O P_{>1}}{O P_{1}}
$$

Eq. 1 


\section{Results}

The Olsen-P extractability of soluble $\mathrm{P}$ added to the soil samples decreased over time, regardless of the type of soil and the type of fertilizer. The Olsen-P extracted 24 hours immediately after the $\mathrm{P}$ addition represented between 10 and $66 \%$ of the P added, depending on the type of soil and the type of fertilizer (MKP or TSP). Thus, the Andisols were observed to have the lowest extractions of Olsen-P, while the highest values were found in Mollisol and Vertisol soils. Likewise and regardless of the type of soil, a greater extraction of Olsen-P occurred when the source of $\mathrm{P}$ was MKP instead of TSP (Figure 1) The extractability of Olsen-P over time was described by an exponential model with one phase of association for the 10 evaluated soils. The equation parameters $(a, b)$ varied depending on the source of $\mathrm{P}(p<0.05)$, registering larger values of Olsen-P when the source of $\mathrm{P}$ was MKP compared to values when TSP was the source. The $k$ parameter related to the loss of Olsen-P extractability, showed no differences $(p>0.05)$ in 9 of the 10 soils, with the exception of the Cudico soil (Figure 1). The a parameter was variable among the soils, showing Olsen-P extractions between 52 and $330 \mathrm{mg} \mathrm{P} \mathrm{kg}^{-1}$ in the Malihue and Malacatos soils, respectively (6 times of variation). The values of the $\mathrm{P}$ extracted by Olsen-P from TSP and MKP were related, a linear relation was found, independent of the soil type (Figure 2). The fitted equation showed a slope of 0.695 , implying that when the source was TSP the amount extracted was approximately $70 \%$ of the Olsen-P extracted when the source was MKP (Figure 2)..
The soil samples were characterized in terms of their P retention capacity according to the Saunders methodology. The Saunders retention index was related to the initial retention of the $\mathrm{P}$ added after 24 hours of incubation (CP represented by the slope in Table 2). A general relationship was described between Saunders Index (\%) and $\mathrm{CP}\left(\mathrm{mg} \mathrm{kg}^{-1} / \mathrm{mg} \mathrm{kg}^{-1}\right)(\mathrm{Y}=$ $0.71-0.0058 X ; R^{2}=0.917$, Sy.x $=0.06$ ) showing that when the Saunders index was zero (no retention), the maximum recovery in Olsen-P was $71 \%$ of the $\mathrm{P}$ added. With the increase of the $\mathrm{P}$ retention according to the Saunders index a decrease in the $\mathrm{P}$ extracted by Olsen-P until when Saunders indicates $100 \%$ of retention the Olsen-P extracts $13 \%$ of the $\mathrm{P}$ added.

The relationships among the CP parameter and the parameters of the equation fitted to the residual value of the $\mathrm{P}$ added to soils are shown in Table 3. The linear relations between $\mathrm{CP}$ and the " $a$ " and " $b$ " parameters of the fitted equation were adequate for all the soils and varied with the soil type according to each soils' retention capacity. The $\mathrm{CP}$ value was able to explain over $90 \%$ of the changes observed in the " $a$ " and " $b$ " parameters. Nevertheless, the proportion of the increase of $a$ and of $b$ (Table 3 ) which corresponded to each unit of CP differed $(p<0.05)$ depending on the source of soluble $\mathrm{P}$, being greater when the source was MKP compared to TSP. The " $a$ " and " $b$ " parameters proved to be linearly related (Table 3). When analysing the CP variation in relation to the $k$ parameter of the equation, the variation in the relationship was not clear. The tendency to decrease the $k$ parameter value with an increase in the CP value was not significant $(p>0.05$, Table 3$)$. 

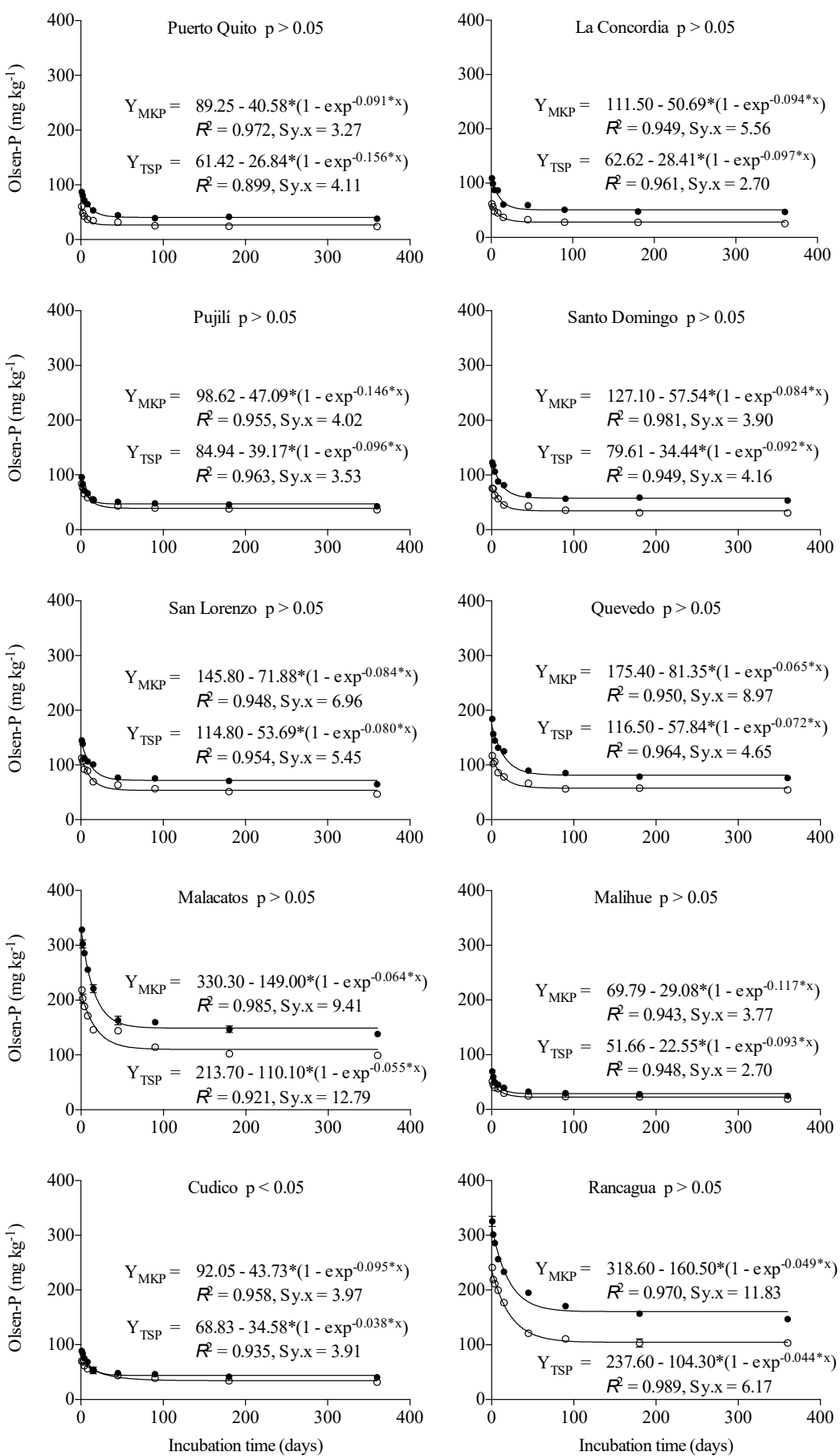

Figure 1. The effect of time on the amount of Olsen-P extracted from 10 contrasting soil samples fertilized with MKP $(\bullet)$ and TSP (o). Each dot represents $\pm \operatorname{SEM}(\mathrm{n}=2)$; $\mathrm{p}$ values $>0.05$ indicate no difference in the parameter $k$. 


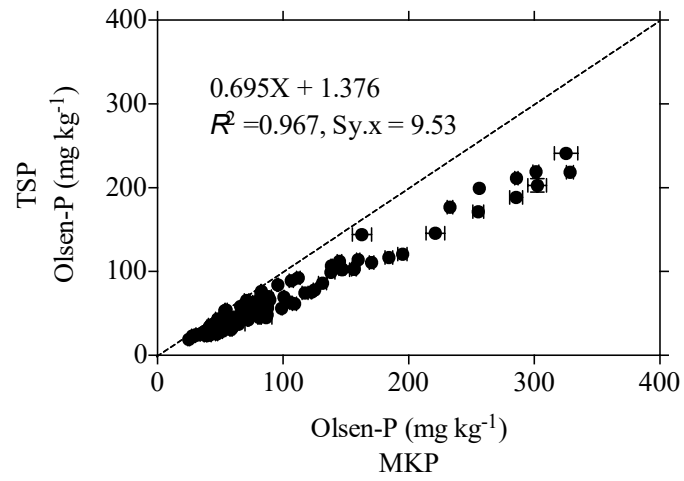

Figure 2. Difference of extraction of Olsen-P in 10 contrasting soils when fertilized with MKP instead of TSP.

Each dot represents $\quad \bar{X} \pm \operatorname{SEM}(\mathrm{n}=2)$

Table 2. Regression parameters relating to the extractability of Olsen-P $\left(\mathrm{mg} \mathrm{P} \mathrm{kg}^{-1}\right)$ and the rate of phosphorus ( $\mathrm{mg} \mathrm{P} \mathrm{kg}^{-1}$ ) added to the soil.

\begin{tabular}{|c|c|c|c|c|c|}
\hline $\begin{array}{l}\text { Soil types and } \\
\text { country of origin }\end{array}$ & $b$ & $a$ & $R^{2}$ & $S_{y . x}$ & $\begin{array}{c}\text { Level of } \\
\text { significance }\end{array}$ \\
\hline \multicolumn{6}{|l|}{ Ecuador } \\
\hline \multicolumn{6}{|l|}{ Andisol } \\
\hline Pto. Quito & 0.194 & -8.712 & 0.997 & 1.569 & $*$ \\
\hline La Concordia & 0.206 & -6.336 & 0.991 & 3.044 & $*$ \\
\hline Pujilí & 0.214 & -14.150 & 0.994 & 2.674 & * \\
\hline Sto. Domingo & 0.256 & -6.915 & 0.955 & 8.778 & * \\
\hline \multicolumn{6}{|l|}{ Inceptisol } \\
\hline San Lorenzo & 0.305 & -13.270 & 0.997 & 2.660 & $*$ \\
\hline Quevedo & 0.411 & -22.430 & 0.991 & 6.157 & $*$ \\
\hline \multicolumn{6}{|l|}{ Vertisol } \\
\hline Malacatos & 0.728 & -30.070 & 0.981 & 16.020 & $*$ \\
\hline \multicolumn{6}{|l|}{ Chile } \\
\hline \multicolumn{6}{|l|}{ Andisol } \\
\hline Malihue & 0.140 & -7.222 & 0.946 & 5.280 & $*$ \\
\hline \multicolumn{6}{|l|}{ Ultisol } \\
\hline Cudico & 0.279 & -13.150 & 0.991 & 4.196 & $*$ \\
\hline \multicolumn{6}{|l|}{ Molisol } \\
\hline Rancagua & 0.645 & -12.270 & 0.979 & 14.90 & $*$ \\
\hline
\end{tabular}

" $b$ ", slope. " $a$ ", intercept. $\mathrm{R}^{2}$, coefficient of determination. Sy.x, standard error. *, significant at $p<0.05$. 
Table 3. Correlation between capacity of $\mathrm{P}(\mathrm{CP})$ and the parameters of the exponential equation $(a, b$ and $k)$ derived from Olsen-P being extracted from contrasting soils and fertilized with MKP and TSP.

\begin{tabular}{|c|c|c|c|c|c|c|c|}
\hline \multicolumn{2}{|l|}{ Correlation } & $\begin{array}{l}\text { Source of } \\
\text { phosphate }\end{array}$ & Slope & & Intercept & $R^{2}$ & Sy.x \\
\hline \multirow{6}{*}{$\begin{array}{l}\mathrm{CP}\left(\mathrm{mg} \mathrm{kg}^{-1} / \mathrm{mg}\right. \\
\left.\mathrm{kg}^{-1}\right)\end{array}$} & \multirow[b]{2}{*}{$a$} & MKP & 465.5 & \multirow{2}{*}{$*$} & -1.40 & 0.970 & 17.3 \\
\hline & & TSP & 317.3 & & 1.98 & 0.933 & 18.0 \\
\hline & \multirow{2}{*}{$b$} & MKP & 224.1 & \multirow[t]{2}{*}{ : } & -2.57 & 0.952 & 10.6 \\
\hline & & TSP & 156.7 & & -1.75 & 0.972 & 5.6 \\
\hline & \multirow[b]{2}{*}{$k$} & MKP & -0.1 & \multirow[b]{2}{*}{$\mathrm{ns}$} & 0.12 & 0.557 & 0.02 \\
\hline & & TSP & -0.1 & & 0.11 & 0.386 & 0.03 \\
\hline
\end{tabular}

*, indicate difference in the slope ( $\mathrm{p}$ values $<0.05$ ). ns, indicate no difference in the slope ( $\mathrm{p}$ values $>0.05$ ). $\mathrm{R}^{2}$, coefficient of determination. Sy.x, standard error.

Because the " $k$ " parameter values were not significant different among soils, it was possible to describe a general kinetics for the $\mathrm{P}$ added to the 10 soil samples over time, expressing Olsen-P extraction in relative term and discounting the initial effect on the P residual value. The differences among the types of soils evaluated and among the fertilizer sources evaluated did not affect the kinetics of $\mathrm{P}$ added in function of time. The " $a$ " and " $b$ " parameters of the new fitted equation were shown to be very conservative under the conditions of this study ( $\mathrm{Y}$ $=1.004-0.470\left(1-\exp (-0.081 \mathrm{X}) ; \mathrm{R}^{2}=0.921 ;\right.$ Sy.x $=$ 0.06 ). Furthermore, it was possible to observe that the maximum amount of Olsen-P extraction did not exceed $53 \%$ (365 days after the $\mathrm{P}$ addition) of the $\mathrm{P}$ extracted immediately after the $\mathrm{P}$ addition (24 hours after the $\mathrm{P}$ addition), that is to say that $47 \%$ of the Olsen-P initially extractable could not be recovered by the Olsen-P extraction. The equation also showed that the maximum half-life registered did not exceed 9 days.

\section{Discussion}

The soils $\mathrm{P}$ retention capacity was related to colloids reactivity, influencing $\mathrm{P}$ availability, and was shown related to $\mathrm{Al}$ extracted by ammonium acetate with a
$\mathrm{pH}$ of $4.8\left(\mathrm{Al}_{\text {ext }}\right)$ which is used in Chile to estimate the soil P retention (Rodríguez et al., 2001). No clear relations were found with the clay content, implying that colloids reactivity was differed among soils (Javid and Rowell, 2002). The residual value of one $\mathrm{P}$ application showed that the extractability declined over time until reaching a stationary state, or nearly so. This was similar in all of the studied soils, and was described using non-lineal models (Motulsky, 2007) as had been previously described using Olsen-P by Barrow and Mendoza (1990) and for Chilean soils by Pinochet (2000). Nonetheless, it has never been described for Ecuadorian soils and they showed similar behaviour. The tendency to reach a stationary state after the initial reaction was apparent after 60 days of incubation at $25{ }^{\circ} \mathrm{C}$ and shows that the initial reaction continues for a period of time until a steady state is reached between the soil and phosphate applied. The fact that only one general equation describes the process in all of the soils indicated that the initial Olsen-P value is related to its final value in all of the soils evaluated. Thus, $\mathrm{P}$ retention appeared to be regulated by a constant rate of loss of extractability ( $k$ in the equation fitted, Figure 1) declining over time until reaches a stationary state. The fact that $\mathrm{k}$ parameter was not related to the reten- 
tion capacity of the studied soils, implying that the loss of $\mathrm{P}$ extractability in Olsen-P over time is most likely related to phenomena that occur in the initial reaction between the fertilizer and the soil. This could be related to the initial phosphate precipitation after the fertilizers dissolution (McLaughlin et al., 2011). Consequently, after the initial precipitation, resolubilisation occurs (Montalvo et al., 2014) and the $\mathrm{P}$ reactions are thus governed by diffusion, and a stationary state, similar to equilibria, is reached (Barrow, 2015). This would explain the process of construction and preservation of phosphorus fertility used in Chile in the soil recovery program after $\mathrm{P}$ depletion, which was modelled by Pinochet (2000). The increase of $\mathrm{P}$ availability indicated by Olsen-P, after the $\mathrm{P}$ application, has also been demonstrated in Ecuadorian Andisols (Cordova et al., 1996) and Inceptisols (Aulakh et al., 2007), cultivated with potatoes and corn, respectively. Furthermore, this phenomenon has been described by Syers et al. (2008) and was proposed as a model by FAO for many soils. The Saunders $\mathrm{P}$ retention index was related to the quick retention capacity of the soil measured by Olsen-P after 24 hours of the $\mathrm{P}$ application (CP).

This shows that both parameters were related, implying that $\mathrm{CP}$ could be used as a $\mathrm{P}$ retention index of soils. A similar parameter was used by Rodriguez (1993) in almost all types of Chilean agricultural soils to characterize them according to their P retentions. The strong affinity between both ways of measuring $\mathrm{P}$ retention implies that this trait is also related mainly to colloids. Its advantage over the Saunders index is that CP discriminates varies well among different types of Andisols, which must be over $90 \%$ according to the Saunders index in order to classify as an Andisol. This narrow range would be adequate for classification purposes, but is insufficient for soil fertility management.
As was expected, the $\mathrm{CP}$ parameter was also related to the " $a$ " parameter of the exponential equation fitted to the residual value of applied $\mathrm{P}$, ratifying that both the $\mathrm{CP}$ and " $a$ " parameters were related to the $\mathrm{P}$ retention capacity of the studied soils. Regardless of the initial magnitude of the Olsen-P value after a $\mathrm{P}$ addition ( $\mathrm{P}$ added minus the $\mathrm{P}$ extracted 24 hours after this addition), the loss of $\mathrm{P}$ extractability was highly associated in neutral to acidic soil with its colloid mineralogy, humus-aluminium complexes, or the presence of $\mathrm{Fe}$ hydroxides presence (Redel et al., 2015). Also, in in neutral to alkaline soils, the loss of extractability was related to the clay mineralogy and changes in the presence of free $\mathrm{CaCO}_{3}$ content (Javid and Rowell, 2002). Both fertilizer sources evaluated were mainly soluble; the $\mathrm{P}$ in TSP is $70 \%$ soluble in water and that in MKP is $100 \%$ soluble in water, which has been previously reported (Schefe et al., 2007). The fact that in all of the studied soils the Olsen-P extracted more from MKP than TSP treatments is interesting and the slope of the linear relation almost coincides with the $70 \%$ of water solubility of the P content in TSP could imply that the values provided by the Olsen-P test account for $\mathrm{P}$ which is solubilised in the soil and do not for $\mathrm{P}$ that was not solubilised, which could remain in other reservoirs that are not detected by Olsen-P. This could have implications on the evaluation of the $\mathrm{P}$ that is accumulating in soils, indicating that Olsen-P values only report the $\mathrm{P}$ that is solubilised.

When the effect of the initial fast reaction was eliminated and P-Olsen extractions were expressed in relative terms (for all soil samples evaluated), the Olsen-P extractability was well explained by only one equation as a function of time $\left(\mathrm{R}^{2}>0.90, \mathrm{n}=180\right)$. This supports the assumption that fast reactions depend on colloids and their proportion in the soil, while slow reactions depend on the laws that govern the dissemination of ions (Barrow, 2015). The close relationship observed between the " $a$ " and " $b$ " parameters of the 
exponential equation with respect to the $\mathrm{CP}\left(\mathrm{R}^{2}>\right.$ 0.90) was also consistent with the P retention index of the soil, which had a considerable effect on the initial loss of P extractability, and all the soils were similar over time in the loss of extractability.

\section{Conclusions}

After adding fertilizer there is a marked initial effect followed by a progressive loss of Olsen-P extractability. Furthermore, over time, a state of quasi-equilibrium or a stationary state is evident, during which the loss of Olsen-P extractability is minimal. The initial effect of the fertilizer's addition and the similar loss of $\mathrm{P}$ extractability among the various soils could be independent of the type of fertilizer (MKP or TSP). When the initial quick reaction in soils was removed, the rate of the loss of extractability was similar in the diverse soils, regardless of the degree of the reactivity of $\mathrm{P}$ with the soil and the source of the soluble P fertilizer (MKP or TSP). The effect of time in the relative residual character of Olsen-P can be relatively well explained by an exponential model of a decline phase, which suggests that after a fertilization event, the $\mathrm{P}$ concentration reaches a stationary state at a higher level regarding the concentration before the fertilization event.

\section{Acknowledgements}

We would like to thank the Ministry of Higher Education, Science and Technology of Ecuador and the Organization of American States for the scholarship given to Gregorio Vásconez (doctoral study). Similarly, we express special thanks to Ruth Espinoza for her invaluable assistance with laboratory tests.

\section{References}

AOAC. 1990. Official methods of analysis. 15th Ed. Association of official Analytical Chemists. Washington, DC, 684 p.

Aulakh, M.S., Garg, A.K., Kabba, B.S. 2007. Phosphorus accumulation, leaching and residual effects on crop yields from long-term applications in the subtropics. Soil Use Manage. 23, 417-427.

Barrow, N.J. 1983. A mechanistic model for describing the sorption and desorption of phosphate by soil. J. Soil Sci. 34, 733-750.

Barrow, N.J. 2015. Soil phosphate chemistry and the P-sparing effect of previous phosphate applications. Plant Soil. 397, 401-409.

Barrow, N.J. 2017. The effects of $\mathrm{pH}$ on phosphate uptake from the soil. Plant Soil. 410, 401-410.

Barrow, N.J., Mendoza, R.E. 1990. Equations for describing sigmoid yield responses and their application to some phosphate responses by lupins and by subterranean clover. Fert. Res. 22, 181-188.

Beinroth, F.H., Luzio, W.L., Maldonado, F., Eswaran, H. 1985. Proceedings of the Sixth International Soil Classification Workshop, Chile and Ecuador. Part III: Tourguide for Chile. Sociedad Chilena de la Ciencia del Suelo, Santiago, Chile, 188 p.

Buytaert, W., Deckers, J., Wyseure, G. 2007. Regional variability of volcanic ash soils in south Ecuador: The relation with parent material, climate and land use. Catena. 70, 143-154.

Cordova, J., Valverde, F. Espinosa, J. 1996. Phosphorus residual effect in andisols cultivated with potatoes. Better Crops. 10, 6-8.

Frossard, E., Achat, D.L., Bernasconi, S.M., Bünemann, E.K., Fardeau, J.C., Jansa, J., Morel, C., Rabeharisoa, L., Randriamanantsoa, L., Sinaj, S., 
Tamburini, F., Oberson, A. 2011. The use of tracers to investigate phosphate cycling in soil-plant systems. In: E.K. Bünemann et al. (editors). Phosphorus in Action. Springer Verlag. pp: 59-91.

Havlin, J.L., Tisdale, S.L., Beaton, J.D., Werner, L.N. 2005. Soil fertility and nutrient management. 8th Ed. Pearson Prentice Hall. Upper Saddle River, US, $528 \mathrm{p}$.

Javid, S., Rowell, D.L. 2002. A laboratory study of the effect of time and temperature on the decline in Olsen P following phosphate addition to calcareous soils. Soil Use Manage. 18, 127-134.

Luzio W. 2010. Suelos de Chile. Editorial MAVAL. Santiago, Chile, $261 \mathrm{p}$.

MAGAP. 2002. Mapa de suelos del Ecuador continental (Variable Taxonomía), escala 1:250000.

Matus, F. Rodríguez, J., Pinochet, D. 2005. Soil Fertility: a rational method of interpretation. Workshop of 9th International Symposium of soil and plant analysis. Cancun, Mexico, 89 p.

McLaren, L.T., McLaughlin, J.M., McBeath, M.T., Simpson, J.R., Smernik, J.R., Guppy, N.C., Richardson, E.A. 2016. The fate of fertiliser P in soil under pasture and uptake by subterraneum clover - a field study using 33P-labelled single superphosphate. Pant Soil. 401, 23-38.

McLaughlin, M., McBeath, T., Smernik, R., Stacey, S., Ajiboye, B., Guppy, C. 2011. The chemical nature of $\mathrm{P}$ accumulation in agricultural soils-implications for fertilizer management and design: an Australian perspective. Plant Soil. 349, 69-87.

Montalvo, D., Degryse, F., McLaughlin, M.J. 2014. Fluid Fertilizers Improve Phosphorus Diffusion but not Lability in Andisols and Oxisols. Soil Sci. Soc. Am. J. 78, 214-224.

Montalvo, D., Degryse, F., McLaughlin, M.J. 2015. Natural Colloidal P and its Contribution to Plant P Uptake. Environ. Sci. Technol. 49, 3427-3434.
Motulsky, H.J. 2007. Prism 5 Statistics Guide. GraphPad Software Inc. San Diego, US. Available in: http://www.graphpad.com/guides/prism/5/ user-guide/prism5help.html? Using_regression _guide_2.htm

Pinochet, D. 2000. Agronomic vision of Olsen-P Simposio: "Normalización de técnicas de acreditación de laboratorios para el análisis de suelos y de tejidos vegetales". Boletín de la Sociedad Chilena de la Ciencia del Suelo. 16, 89-98.

Redel, Y.D; Escudey, M; Alvear, M; Conrad, J; Borie, F. 2015. Effects of land use change on P bioavailability determined by chemical fractionation and 31P-NMR spectroscopy in a Nothofagus forest and adjacent grassland. J. Soil Sci. Plant Nutr. 15, 1061-1070.

Rodríguez, J. 1993. La fertilización de los cultivos: un método racional. Colección en Agricultura, Facultad de Agronomía, Pontificia Universidad Católica de Chile. Santiago, Chile, 291 p.

Rodríguez, J., Pinochet, D., Matus, F. 2001. Fertilización de los cultivos. LOM ediciones. Santiago, Chile, 117 p.

Sadzawka, S.A., Carrasco, S.M.A., Grez, S.R., Mora, S.M.L. 2004. Métodos de análisis recomendados para suelos chilenos. Comisión de normalización y acreditación Sociedad Chilena de la Ciencia del Suelo. Chile, 164 p.

Sandaña, P., Pinochet, D. 2014. Phosphorus acquisition of wheat, pea and narrow-leafed lupin under different P supplies. J. Soil Sci. Plant Nutr. 14, 973-986.

Sandoval, M., Dörner, J., Seguel, O., Cuevas, J., Rivera, D. 2012. Métodos de análisis físicos de suelos. Departamento de Suelos y Recursos Naturales. Universidad de Concepción. Chile, 80 p.

Saunders, W.M.H. 1965. Phosphate retention by New Zealand soils and its relationship to free sesqui- 
oxides, organic matter and other soil properties. N.Z.J. Agric. Res. 8, 30-37.

Schefe, C.R., Patti, A.F., Clune, T.S., Jackson, W.R. 2007. Soil amendments modify phosphate sorption in an acid soil: the importance of $\mathrm{P}$ source $\left(\mathrm{KH}_{2} \mathrm{PO}_{4}\right.$, TSP, DAP). Aust. J. Soil Res. 45, 246254.

Selles, F., Campbell, C.A., Zentner, R.P., Curtin, D., James, D.C., Basnyat, P. 2011. Phosphorus use efficiency and long-term trends in soil available phosphorus in wheat production systems with and without nitrogen fertilizer. Can. J. Soil Sci. 91, 39-52.

Sharpley, A.N., Jones, C.A., Gray, C., Cole, C.V. 1984. A simplified soil and plant phosphorus model: II. Prediction of labile, organic and sorbed phosphorus. Soil Sci. Soc. Am. J. 48, 805-809.
Syers, J.K., Johnston, A.E., Curtin, D. 2008. Efficiency of soil and fertilizer phosphorus use: reconciling changing concepts of soil phosphorus behaviour with agronomic information. FAO Fertilizer and Plant Nutrition. Bulletin 18, 108 p.

Velásquez et al, 2016. Fertilizer effects on phosphorus fractions and organic matter in Andisols. J. Soil Sci. Plant Nutr. 16, 294-304.

Ziadi, N., Whalen, J.K., Messiga, A.J., Morel, C. 2013. Assessment and Modeling of Soil Available Phosphorus in Sustainable Cropping Systems. Adv. Agron. 122, 85-126. 